\title{
CLIMATIC CHARACTERISTICS OF FOREST VEGETATION ZONES OF THE CZECH REPUBLIC
}

\author{
JAROMÍR MACKU゚ \\ ÚHÚL Brandýs nad Labem, pobočka Brno, Vrázova 1, 63800 Brno, e-mail: \\ macku.jaromir@uhul.cz
}

Received: $9^{\text {th }}$ April 2014, Accepted: $31^{\text {st }}$ October 2014

\begin{abstract}
Correct derivation of climatic characteristics of forest vegetation zones is the Achilles heel of Forest site classification in the Czech Republic. A combination of low density of climatic stations, and their unsuitable location (in regard to distribution of forest complexes) make obtaining data problematic.

An important contribution to this issue is an application of ALADIN-CLIMATE.CZ model materials from the Czech Hydrometeorological Institute (CHMI) for the second time period of normal climate years 1961-1990, and the current period from 1991-2009. Calculation of climatic (temperature, precipitation, etc.) fields was conducted on a basis of observation stations. The original station series were subjected to quality control, meaning they were homogenised and supplemented by missing values in measurements. The actual calculation of the technical series is based on the IDW (Inverse Distance Weighting) method; data is used when surrounding stations are first standardised to altitude point, for which we expect a new line, and then calculated a weighted average of new value. The station data were interpolated using the geostatistical linear kriging method.

The outputs are the spatial averages for basic climatic zonal forest vegetation level, occurring in the different Natural Forest Areas (NFA). The individual climate parameters of forest vegetation zones were evaluated by regression analysis. The climate-vegetation segments (CVS) of the Czech Republic, which share similar climatic characteristics of the forest vegetation zones (FVZ), were proposed.
\end{abstract}

Key words: Forest Vegetation Zone, climate parameters, Natural Forest Area, Climate-Vegetation Segments

\section{INTRODUCTION}

Climatic characteristics of the FVZ are often associated with characteristics of a climatic regionalisation (Quitt, 1971). It is a misconception because there are missing links to occurrence of native tree species (Zlatník, 1976). A limited overview of climatic characteristics of FVZ in Hercynian and Carpathian regions is available in the site classification system of Czech forests (Plíva et al. 1971).

Zlatník (1957) and Ambroz (1977) dealt with climate conditionality of ecological variations of vegetation zones in the former Czechoslovakia. These authors defined two climatic-vegetation zones and their variants. Exact climate data was only bound to CHMI 
climatic stations. An area's definition was derived by expert knowledge of preserved remnants of potential natural vegetation, and an impact of macroclimate on recent vegetation (Tüxen, 1956; Moravec, 1998). The essential idea is to emphasise the inseparable bond of units of potential natural vegetation with characteristics of macroclimate (Major, 1951). There are distinguished leaders of geobiocoenotic type for vegetation-climatic zones: Fageta paupera typica for "non-Fir" and "non-Spruce" area, and conversely Fagi-abieta typica for "Fir" and "Spruce" regions (Zlatník, 1976; Buček \& Lacina, 1999). This corresponds to the course of particular climatic characteristics. The concept of macroclimate inseparable bond to units of potential natural vegetation corresponds to the holistic philosophy, and is a basis for evaluation of climatic characteristics of FVZ. The selection of typology sites corresponding to "the normal sequence of vegetation degrees" is a fundamental aspect for evaluation of climatic data. This means the sequence of forest vegetation zones with increasing altitude from the lowlands to the mountains, thus affected by macroclimate in the territory, is gradually increasing, excluding exposure and inverse mesoclimate (Zlatník, 1976).

This paper aims to clarify climatic characteristics of the forest altitudinal vegetation zones (FVZ) in the Czech Republic.

\section{MATERIAL}

A principle of macroclimatic data evaluation for FVZ follows a close link between representation of typological (site classification system) units and climatic data. Vector maps of forest vegetation zones were an inherent source material for the definition of FVZ (UHUL, 2014). The Climatic Atlas of the Czech Republic (Voženílek, 2007), and documents containing the regionalisation of climatic districts, were an additional resource. Climatic parameters for each typological plot (42 thousand in the Czech territory) were derived based on the Regional Typological Elaborates (RTE, internal materials by UHUL), by method of downscaling to regional climatic areas (Hadaš, 1997). The study "Climatic characteristics of FVZ in the Climate-Vegetation Areas" (Macků, 2010) was the outcome.

Supporting documents of the Czech Hydrometeorogical Institute (CHMI) are main source materials, along with model outputs of the ALADIN-CLIMATE.CZ, in co-operation with the Global Change Research Centre of Academy of Sciences of the Czech Republic. The derived climate data have been processed for zonal FVZ as a part of the Natural Forest Area (NFA) (Janouš et al. 2011; Plíva \& Žlábek. 1986). The zonal FVZ corresponded to the vertical (altitudinal) climatic tiers (Pojar et al,. 1987). Experts of the CHMI Brno branch calculated spatial averages of basic climatic characteristics (the average daily temperature, daily precipitation, average daily wind speed, air humidity and solar radiation) for zonal FVZ, occurring in each NFA.

\section{METHODOLOGY OF DERIVATION OF THE CLIMATIC PARAMETERS}

Calculation of temperature and precipitation fields proceeded on the basis of the observation points. For the calculation, technical lines of stations were used, i.e., that original station series have been subjected to quality control, homogenisation and missing values have been added in measurements (Štěpánek et al., 2009).

The calculation of the series was based on the technical methods of IDW (Inverse Distance Weighting), the data used when the surrounding stations are standardised by altitude, of the point for which we are counting on a new line, and then a new value is calculated by a 
weighted average. Parameter settings differed for each meteorological element (Cudlín et al., 2008). These station data were interpolated in a geostatistical method of the linear kriging desktop, prior to the calculation. The local regression was applied according to the quantities on the altitude, and the weighting factor of the value of the coefficient of determination R2 in each cell of the grid.

Combined with the fact that there are only 131 grid points for the entire territory of the Czech Republic (which represents half of climatological stations, but only one-sixth of precipitation stations), spatial information on most of the territory (especially in areas with rugged terrain) is completely inadequate. Air temperature data were usable, but rainfall data have been, especially outside of the grid points, often inadequate (e.g. for higher altitude during the period 1991-2009, rainfall was undervalued by more than $100 \mathrm{~mm}$ ). Therefore, a different approach was used. The data from the grid points was corrected to positions of the station model, the so-called variable correction method, when each element distribution is corrected by individual fractiles. A few corrections were carried out from the surrounding grid points for the location of the station, which can be used to determine the uncertainty of the calculation.

The first step was to analyse the course of the annual rainfall and average temperatures. The intersection of these values presents a pilot FVZ in a given NFA (1). In the second step, followed by an analysis of control FVZ in NFA. For each FVZ in the NFA were evaluated by regression analysis during annual rainfall and average temperatures. Based on the prediction, results were defined by the Climate-Vegetation Segments (CVS) and their variants. CVS variants are presented by FVZ characteristics of annual rainfall and average temperatures. Variations reflect the relationship between the influence of oceanic (continental) climate-temperature-precipitation and altitude. Normal variant represents a linear progression of precipitation-temperature and altitude. Abnormally high temperatures and low rainfall, in relation to the altitude, characterise the xeric variant. Ombrick (wet) variant option then anomalies at low temperatures - high rainfall.

\section{RESULTS}

\section{Definition of control FVZ in NFA}

Prediction of the annual rainfall and average temperatures and related zonal FVZ was processed for NFAs. An intersection of these values represents a pilot FVZ in a given NFA (Fig 1).

Fig. 1: Prediction of the annual rainfall and average temperatures in the NFA 16 according to $\mathrm{FVZ}$

\begin{tabular}{|c|c|c|c|c|c|}
\hline \multirow{6}{*}{ 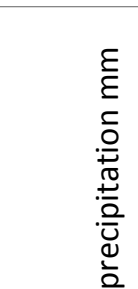 } & \multirow{6}{*}{$\begin{array}{l}710,0 \\
700,0 \\
690,0 \\
680,0 \\
670,0 \\
660,0 \\
650,0\end{array}$} & 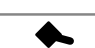 & & & \multirow{9}{*}{ 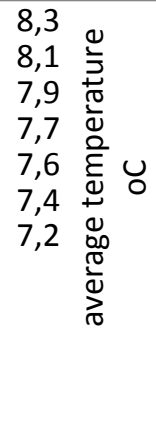 } \\
\hline & & & & & \\
\hline & & & & & \\
\hline & & 3 & & & \\
\hline & & & & & \\
\hline & & 3 & 4 & 5 & \\
\hline$\longrightarrow p$ & ation & & & & \\
\hline & & 669,3 & 691,6 & 701,6 & \\
\hline$-\curvearrowright t$ & ature oC & 8,2 & 7,9 & 7,6 & \\
\hline
\end{tabular}


Macků J.: Climatic characteristics of forest vegetation zones of the Czech Republic

On the basis of the pilot FVZ analysis for each NFA, variants of the Climate-Vegetation Segments (CVS) were designed. Normal variant assumes a balanced course of average temperature and rainfall, a variant of the xeric represents the low temperatures and limited rainfall, and a variant of the ombric is in favour of the precipitation.

Table 1: Representation of the control FVZ in NFA (precipitation $\mathrm{mm}$, average temperature ${ }^{\circ} \mathrm{C}$ )

\begin{tabular}{|c|c|c|r|r|r|r|r|r|r|c|c|}
\hline NFA & FV & precipitation & temperatur & NF & FV & precipitatio & temperatur & NF & FV & precipitatio & temperatur \\
\hline 35 & 1 & 535,0 & 9,9 & 31 & 3 & 718,4 & 8,2 & 1 & & 818,2 & 7,3 \\
\hline $2 \mathrm{~b}, 8 \mathrm{~b}$ & 2 & 586,8 & 9,1 & 32 & 3 & 670,7 & 9,0 & 11 & 5 & 800,0 & 7,5 \\
\hline $8 \mathrm{a}$ & & 544,2 & 8,9 & 33 & 3 & 566,3 & 8,6 & 12 & 5 & 726,0 & 7,1 \\
\hline $15 \mathrm{a}$ & 2 & 597,7 & 8,7 & 36 & 3 & 640,8 & 9,2 & 29 & 5 & 740,0 & 7,4 \\
\hline 17 & 2 & 616,9 & 9,2 & 37 & 3 & 694,9 & 9,0 & 23 & 5 & 900,0 & 6,8 \\
\hline 34 & 2 & 584,7 & 8,7 & 38 & 3 & 805,0 & 8,3 & 28 & 5 & 900,0 & 6,8 \\
\hline $8 \mathrm{a}$ & 3 & 578,0 & 8,5 & 39 & 3 & 793,6 & 8,8 & 40 & 5 & 1239,0 & 6,8 \\
\hline 4 & 3 & 651,5 & 7,9 & $2 \mathrm{a}$ & 4 & 657,5 & 7,9 & 41 & 5 & 980,0 & 7,6 \\
\hline $5 \mathrm{a}$ & 3 & 661,0 & 8,0 & $5 \mathrm{~b}+$ & 4 & 689,9 & 7,3 & 3 & 6 & 700,0 & 7,0 \\
\hline 6 & 3 & 612,9 & 8,2 & 7 & 4 & 662,2 & 8,0 & 14 & 6 & 863,0 & 6,6 \\
\hline 9 & 3 & 532,7 & 8,3 & 16 & 4 & 701,6 & 7,6 & 24 & 6 & 815,0 & 6,2 \\
\hline 10 & 3 & 618,4 & 8,3 & 19 & 4 & 796,6 & 8,3 & 21 & 6 & 1150,0 & 6,3 \\
\hline $15 \mathrm{~b}$ & 3 & 633,4 & 8,3 & 20 & 4 & 903,2 & 8,1 & 22 & 6 & 1300,0 & 5,2 \\
\hline 18 & 3 & 684,3 & 8,2 & 26 & 4 & 833,8 & 7,7 & 25 & 6 & 1170,0 & 5,9 \\
\hline 30 & 3 & 597,9 & 8,5 & 13 & 7 & 1220,2 & 4,9 & 27 & 6 & 1070,0 & 5,4 \\
\hline
\end{tabular}

The parameters of the precipitation and average temperatures of the controlled FVZ have been deducted from the graphs of the prediction of their course.

Demonstration differentiation of climate parameters of the pilot $4 \mathrm{FVZ}$ in the represented NFA:

Fig 2: The parameters of annual rainfall and average temperatures for the 4th FVZ in NFA

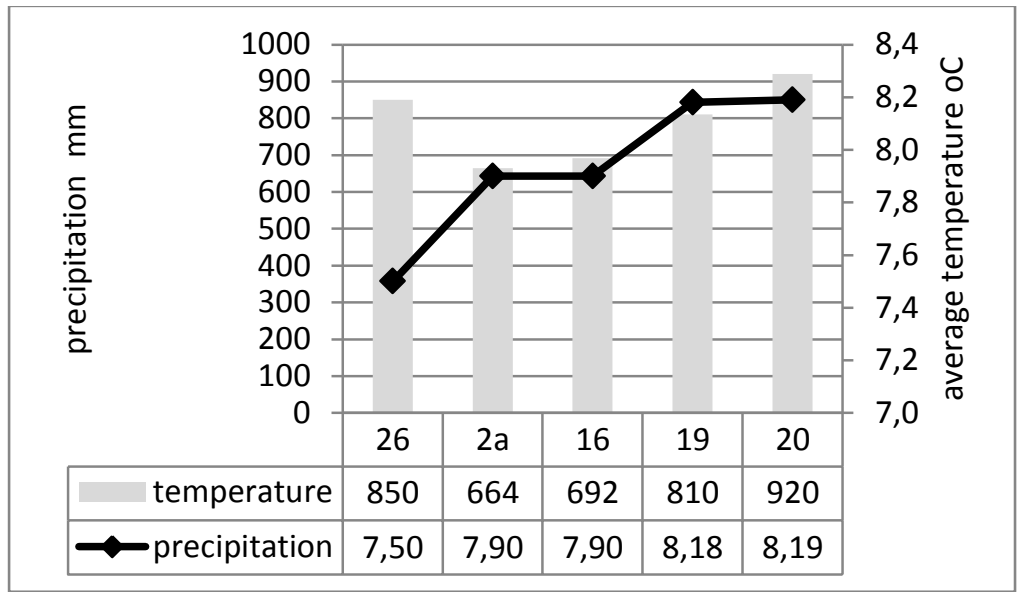


Fig 2 shows the climate parameters of the NFA for the pilot 4-th. FVZ. Difference between temperature and rainfall implies the definition of a variant CVS, as it is apparent from their derivation.

Demonstration processing during the regression analyses of precipitation and average temperatures:

Fig 3: Process of precipitation in the $8^{\text {th }} \mathrm{FVZ}$ according to NFA

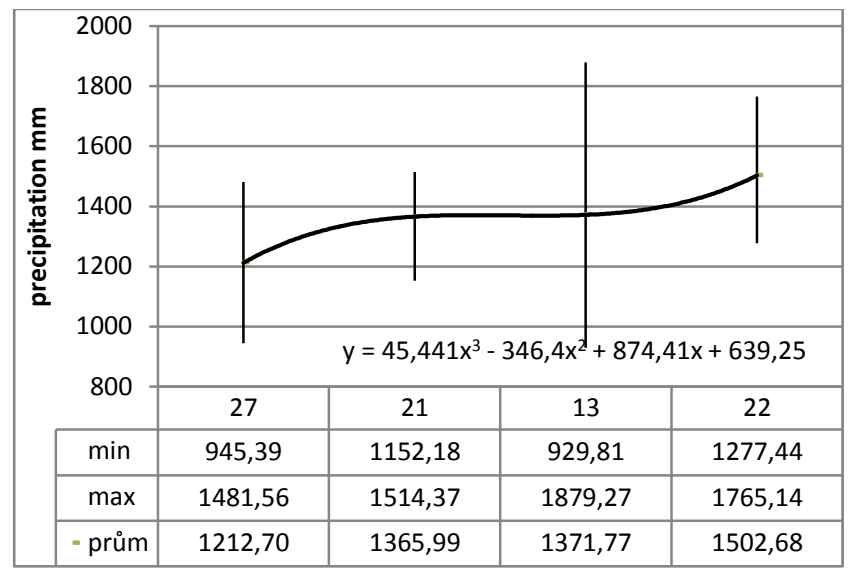

Fig 4: Process of temperature in the $8^{\text {th }}$ FVZ according to NFA

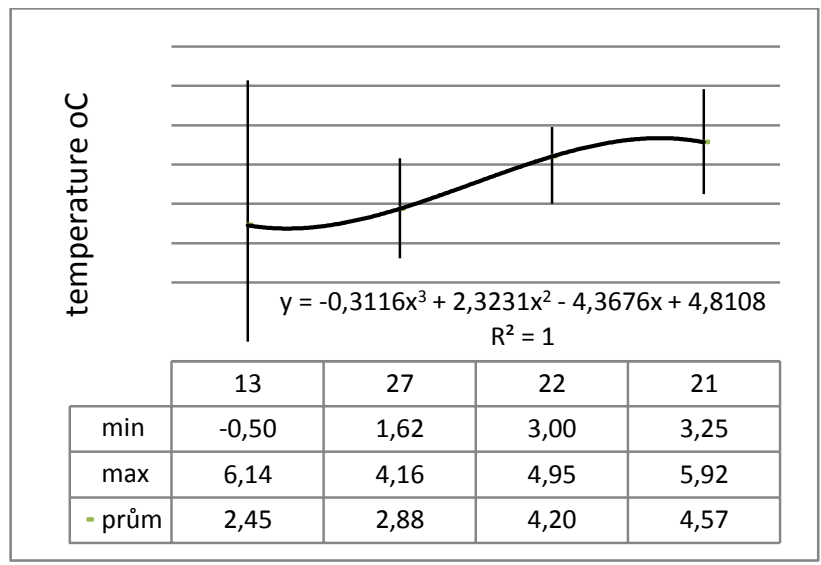

The analysis documented a significant variance of observed parameters in the investigated FVZ. On this basis, it is possible to predict the variation of CVS. 
Macků J.: Climatic characteristics of forest vegetation zones of the Czech Republic

Proposal of the CVS and their variants by control FVZ

Table 2: Climate-Vegetation Segments of forest vegetation zones in NFAs

\begin{tabular}{|c|r|r|r|r|}
\hline \multicolumn{2}{|c|}{ CVS } & \multicolumn{3}{c|}{ variant } \\
\hline symbol & name & X & N & O \\
\hline $\mathbf{1}$ & oak & $\mathbf{3 5}$ & $\mathbf{1 5 a}, \mathbf{1 7 , 3 4}$ & \\
\hline $\mathbf{2}$ & beech-oak & $\mathbf{2 b , 8 b}$ & $\mathbf{2 a , 5 b + c , 7 , 1 6 , 1 9}$ & $\mathbf{2 0 , 2 6}$ \\
\hline $\mathbf{3}$ & oak-beech & $\mathbf{8 a}$ & $\mathbf{4 , 5 a , 6 , 9 , 1 0 , 1 5 b , 1 8 , 3 0 , 3 1 , 3 2 , 3 3 , 3 6 , 3 7}$ & $\mathbf{3 8 , 3 9}$ \\
\hline $\mathbf{4}$ & beech & & $\mathbf{1 1 1 , 1 2 , 2 9}$ & $\mathbf{2 3 , 2 8 , 4 0 , 4 1}$ \\
\hline $\mathbf{5}$ & fir-beech & & $\mathbf{3 , 1 4 , 2 4}$ & $\mathbf{2 1 , 2 2 , 2 5 , 2 7}$ \\
\hline $\mathbf{6}$ & spruce-beech & & & $\mathbf{1 3}$ \\
\hline $\mathbf{7}$ & beech-spruce,spruce & & & \\
\hline
\end{tabular}

A total of seven CVS with three variations is proposed. A variant of Xeric (3 in total), Normal (5), and Ombric (5), in total 13 variants. Parameters of climate data with the zonal FVZs are shown in Table 3. 
Journal of Landscape Ecology (2014), Vol: 7 / No. 3

Table 3: The climatic parameters of FVZ in CVS

\begin{tabular}{|c|c|c|c|c|c|c|c|c|}
\hline \multicolumn{2}{|c|}{ CVS } & \multirow[t]{2}{*}{ FVZ } & \multicolumn{3}{|c|}{ temperature $\left({ }^{\circ} \mathrm{C} /\right.$ year$)$} & \multicolumn{3}{|c|}{ precipitation $(\mathrm{mm} /$ year $)$} \\
\hline symbol & version & & $\min$ & $\max$ & mean & $\min$ & $\max$ & mean \\
\hline \multirow[t]{3}{*}{1} & $\mathbf{x}$ & 1 & 9,3 & $\mathbf{1 0 , 3}$ & 9,9 & 429,5 & 652,6 & 534,6 \\
\hline & & 2 & 9,2 & 10,2 & 9,9 & 444,7 & 632,6 & 535,4 \\
\hline & & 1 & 8,5 & 9,3 & 8,8 & 442,6 & 584,3 & 492,5 \\
\hline \multirow[t]{2}{*}{2} & $\mathbf{x}$ & 2 & 8,4 & 10,2 & 9,0 & 428,0 & 723,7 & 565,5 \\
\hline & & 1 & 8,3 & 10,2 & 9,3 & 443,3 & 758,2 & 569,0 \\
\hline \multirow[t]{3}{*}{2} & $\mathbf{n}$ & 2 & 8,4 & 9,9 & 9,0 & 468,1 & 725,8 & 600,8 \\
\hline & & 3 & 8,2 & 9,1 & 8,6 & 565,4 & 734,7 & 638,4 \\
\hline & & 2 & 8,2 & 10,6 & 8,9 & 441,6 & 669,1 & 544,2 \\
\hline \multirow[t]{3}{*}{3} & $\mathbf{x}$ & 3 & 7,8 & 9,5 & 8,5 & 460,5 & 672,2 & $\mathbf{5 7 7 , 9}$ \\
\hline & & 1 & 8,3 & 9,8 & 9,2 & 485,7 & 653,8 & 543,3 \\
\hline & & 2 & 7,7 & 9,7 & 8,8 & 490,4 & 733,5 & 587,3 \\
\hline \multirow[t]{4}{*}{3} & $\mathbf{n}$ & 3 & 7,3 & 9,4 & 8,4 & 509,9 & 816,3 & 637,2 \\
\hline & & 4 & 7,2 & 8,8 & 8,0 & 548,2 & 825,3 & 663,7 \\
\hline & & 5 & 6,8 & 8,2 & 7,4 & 614,2 & 945,3 & 754,8 \\
\hline & & 2 & 7,6 & 9,5 & 8,8 & 541,7 & 1027,3 & 729,5 \\
\hline \multirow[t]{4}{*}{3} & o & 3 & 7,4 & 9,5 & 8,6 & 602,8 & 1159,6 & 799,3 \\
\hline & & 4 & 6,4 & 8,9 & 7,9 & 714,1 & 1384,2 & 969,6 \\
\hline & & 2 & 8,2 & 9,8 & 8,8 & 518,5 & 639,4 & 579,4 \\
\hline & & 3 & 7,4 & 9,3 & 8,2 & 538,1 & 857,7 & 680,0 \\
\hline \multirow[t]{5}{*}{4} & $\mathbf{n}$ & 4 & 7,2 & 8,7 & 8,0 & 593,3 & 847,8 & 702,0 \\
\hline & & 5 & 6,4 & 8,9 & 7,6 & 561,4 & 1007,4 & 762,1 \\
\hline & & 6 & 6,4 & 7,9 & 7,1 & 700,0 & 1034,3 & 880,1 \\
\hline & & 2 & 8,0 & 9,1 & 8,6 & 598,7 & 785,1 & 684,5 \\
\hline & & 3 & 7,6 & 8,9 & 8,3 & 657,9 & 999,5 & 815,4 \\
\hline \multirow[t]{6}{*}{4} & o & 4 & 6,9 & 8,8 & 7,9 & 730,8 & 1081,7 & 868,5 \\
\hline & & 5 & 6,4 & 8,2 & 7,4 & 800,8 & 1078,9 & 924,0 \\
\hline & & 6 & 5,8 & 5,9 & 5,8 & 1048,0 & 1115,5 & 1084,0 \\
\hline & & 2 & 7,7 & 9,2 & 8,6 & 538,6 & 764,3 & 631,5 \\
\hline & & 3 & 7,3 & 8,9 & 8,3 & 549,4 & 846,8 & 696,5 \\
\hline & & 4 & 6,7 & 8,6 & 7,8 & 582,1 & 895,3 & 718,0 \\
\hline \multirow[t]{7}{*}{5} & n & 5 & 5,8 & 8,5 & 7,2 & 598,3 & 1103,2 & 782,5 \\
\hline & & 6 & 5,3 & 7,9 & 6,6 & 675,4 & 1321,6 & 894,7 \\
\hline & & 7 & 4,7 & 7,2 & 5,9 & 784,3 & 1266,9 & 1021,6 \\
\hline & & 8 & 4,15 & 5,79 & 5,02 & 898,84 & 1051,91 & 984,17 \\
\hline & & 2 & 7,6 & 9,2 & 8,6 & 601,1 & 785,6 & 683,7 \\
\hline & & 3 & 7,09 & 9,36 & 8,27 & 597,39 & 968,94 & 749,73 \\
\hline & & 4 & 6,4 & 8,8 & 7,8 & 685,4 & 1230,7 & 899,3 \\
\hline \multirow[t]{6}{*}{5} & o & 5 & 5,0 & 8,6 & 6,9 & 738,1 & 1445,5 & 1022,2 \\
\hline & & 6 & 4,4 & 7,1 & 5,7 & 885,9 & 1544,1 & 1164,7 \\
\hline & & 7 & 3,6 & 5,2 & 4,4 & 1287,7 & 1465,8 & 1387,6 \\
\hline & & 3 & 7,1 & 8,6 & 7,9 & 607,7 & 794,7 & 707,0 \\
\hline & & 4 & 6,1 & 8,3 & 7,3 & 608,0 & 857,4 & 713,9 \\
\hline & & 5 & 5,6 & 8,0 & 6,8 & 654,5 & 941,6 & 768,3 \\
\hline \multirow[t]{5}{*}{6} & $\mathbf{n}$ & 6 & 5,1 & 7,3 & 6,2 & 707,3 & 1019,1 & 852,6 \\
\hline & & 7 & 5,3 & 6,4 & 5,9 & 847,3 & 1047,2 & 931,7 \\
\hline & & 3 & 7,4 & 8,6 & 8,1 & 717,9 & 1063,9 & 880,4 \\
\hline & & 4 & 6,8 & 8,4 & 7,7 & 789,3 & 1147,7 & 959,0 \\
\hline & & 5 & 5,2 & 7,7 & 6,5 & 816,1 & 1278,8 & 1029,7 \\
\hline \multirow[t]{6}{*}{6} & o & 6 & 4,1 & 7,0 & 5,5 & 897,8 & 1467,7 & 1189,3 \\
\hline & & 7 & 3,1 & 5,8 & 4,5 & 1017,7 & 1555,9 & 1335,7 \\
\hline & & 8 & 2,6 & 5,0 & 3,9 & 1125,0 & 1587,0 & 1360,5 \\
\hline & & 9 & 1,7 & 3,8 & 2,9 & 1195,5 & 1654,0 & 1412,8 \\
\hline & & 5 & 5,4 & 8,3 & 7,2 & 651,6 & 1219,5 & 917,9 \\
\hline & & 6 & 2,3 & 8,3 & 6,0 & 655,2 & 1671,3 & 945,5 \\
\hline 7 & $\mathbf{0}$ & 7 & 1,1 & 7,1 & 4,9 & 800,1 & 1806,7 & 1220,2 \\
\hline & & 8 & $-0,5$ & 6,1 & 2,5 & 929,8 & 1879,3 & 1371,8 \\
\hline
\end{tabular}




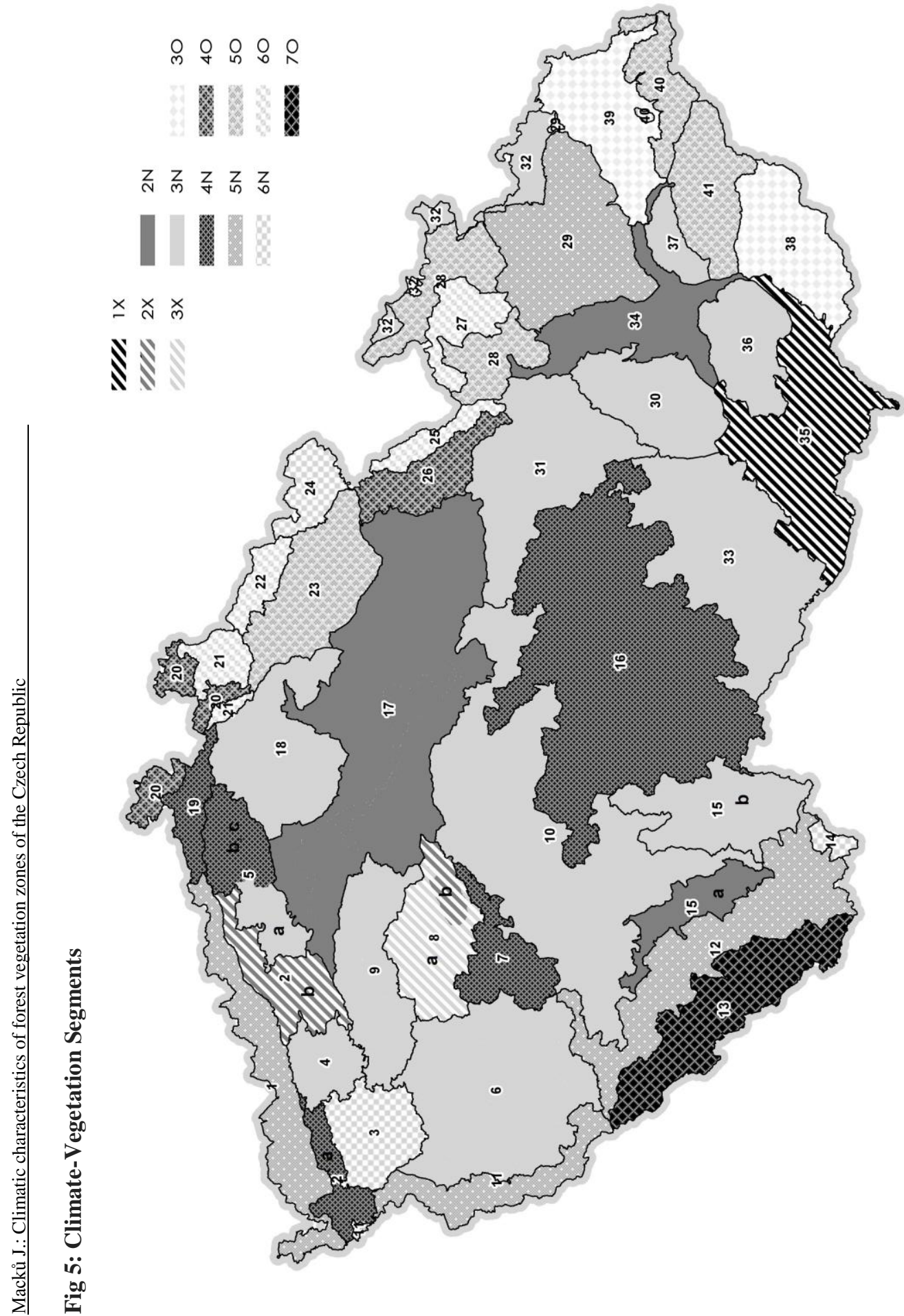




\section{DISCUSSION}

The structure of the typology system of the Forest Management Institute (CS) and the flat character of the Hercynian area creates mosaic character of FVZs (Plíva et al. 1971). The concept of vegetation zonation is not based explicitly on altitude; it is built on the idea of composition of the potential vegetation (Ambroz, 1977). In addition, a species composition in vegetation zones is not uniform, modified by topo-edafic factors (the differences of soil, topography, meso-and microclimate).

In general, temperature is the limiting factor at higher elevations, with relatively high precipitation being the limiting factor at lower elevations (Ambroz, 1977). A negative effect of increased temperature is manifested through increased evapotranspiration. The fourth $\mathrm{FVZ}$ is generally considered the FVZ of the same influence of temperature and precipitation (Ambroz, 1977). Therefore, this FVZ will be considered the range of the increase of importance of temperature, and decrease of importance of rainfall toward higher degrees, and vice versa; the increase in importance of rainfall and importance of temperature towards the lower FVZ. Forest typological plots belonging to zonal forest vegetation zones, which occur on edafic (soil) categories: fresh, rich and acid have been a subject to evaluation of macroclimate (Major, 1951).

Macroclimatic characteristics of FVZ were processed for each NFA to the CVS and their variants. It was, however, necessary to verify the hypothesis of relevance of the quantified CVS and their variants, according to the spectrum and distribution of macroclimatic characteristics of FVZ. This method was used for the regression analyses of macroclimatic data from FVZ. It then started to detail the climatic characteristics of the FVZ by variants of the CVS. Variability of the climatic parameters zonal FVZ is considerable. The term 'segment' is applied instead of the term 'area' for two reasons. The area is viewed as a continuous territory, and the segment represents the way a mosaic of more-or-less model surfaces with approximately the same climatic parameters of the FVZ.

A fundamental lesson, which resulted from the processing of the data, is that the climatic characteristics of the zonal FVZs are indebted with CVSs. The units of NFA allow us to associate the analytical issues with potential and current vegetation.

\section{CONCLUSION}

An important contribution is the application of the model ALADIN-CLIMATE.CZ, from time records of the second climate normal 1961 - 1990 and the current period 1991-2009. Calculation within the field (temperature, precipitation, etc.) took place on the basis of the point of observation. The technical line stations were used for the calculation of analysis, i.e., that the original station series have been subjected to quality control, homogenisation, and missing values have been added in measurements. The series is based on the calculation of the technical methods of IDW, when the data used the surrounding stations are the first standardised on altitude point, for which we are counting on a new line, and then the weighted average counted the new value. These station data are interpolated in the area by the geostatistical method of the linear kriging.

Outputs are spatial averages basic climate data for zonal FVZ occurring in the individual NFA. Parameters of the climate of the individual FVZ were evaluated by regression analyses on this basis, where proposed Climate-Vegetation Segments of the CZECH REPUBLIC combine similar characteristics of the climate in the FVZ. The aim of the contribution was to specify the climate parameters of the zonal FVZ. Due to the large mosaic of natural conditions in the Czech Republic, climate segments are not continuous. 
The results confirmed the link between macroclimate and the units of potential natural vegetation. Each CVS was assigned the leadership of FVZ, and the resulting definition of limiting factors of temperature and precipitation. Documented results also allowed prediction of, and connection with, potential shift of the FVZs as an impact of global climate change. It is possible to follow in detail the offset of the FVZ in each of the variants of the CVS, and preferably the procedure and selection, as follow-up measures. This subsequent discovery is testament to the adaptability of forest stands in the context of the global climate change scenario.

\section{REFERENCES}

Ambroz, Z., (1977). Přehled a stručná charakteristika variant vegetační stupňovitosti ČSFR. Lesnická fakulta VŠZ Brno, 6.str., 1 prŕloha.

Buček, A., Lacina, J. (1999). Geobiocenologie II. MZLU Brno, 978-80-7375-046-6, 251 s.

Cudlín, P., Macků, J., Štěpánek, P., Kohut, M., Rožnovský, J., (2008). Influence of precipitation and temperature in the period 1961-2100 on the possibilities to grow Pice abies in the Czech republic, Bioklimatologické aspekty hodnocení procesů v krajině.

Hadaš, P., (1997). The special program for derivation of climatological data for the territory Moravian-Silesian Beskids. Zpravodaj Beskyd, 9: 229-234.

Janouš, D., Cudlín, P. (2011). Dopady změny klimatu a návrhy adaptačních opatření v sektoru lesnictví, Centrum výzkumu globální změny AV ČR, v.v.i., 19 str. (3 př́lohy).

Voženílek, V. (2007). Climate Atlas of Czechia. Kartografické listy 2008, 16, 24 refs.

Macků, J., (2010). Makroklimatické charakteristiky LVS v Klimaticko-vegetačních oblastech a jejich variantách, ÚHÚL Brandýs n.L., 40 str., 3 př́lohy.

Major, J., (1951). A functional, factorial approach to plant ecology. Ecology, 32: 392-412.

Moravec, J., (1998). Reconstructed natural versus potential natural vegetation in vegetation mapping: a discussion of concepts. Applied Vegetation Science, 1: 173-176.

Plíva, K. (1971): Typologický systém ÚHÚL Brandýs n. L., ÚHÚL Brandýs n.1., 119 str, 8. Př́ll.

Plíva, K., Žlábek, I., (1986). Př́rodní lesní oblasti ČSR. Státni zemědělské nakladatelství, Praha: 313 s.

Pojar, J., Klinka, K, Meidinger, D.V., (1987). Biogeoclimatic ecosystem classification in British Columbia. Forest Ecology and Management, 22: 119-154.

Quitt, E., (1971). Klimatické oblasti Československa. Studia Geographica 16, GÚ ČSAV v Brně: 73 s.

Štěpánek, P., Zahradníček, P. a Skalák, P. (2009). Data quality control and homogenization of air temperature and precipitation series in the area of the Czech Republic in the period 1961-2007. Advances in Science and Research, 3: 23-26.

Tüxen, R., (1956). Die heutige potentielle natürliche Vegetation als Gegenstand der Vegetationskartierung. Angewandte Pflanzensoziologie, 13: 5-55.

ÚHÚL, (2014). Retrieved August 6, 2014, from www.uhul.cz.

Zlatník, A., (1957). Využití generálních typologických map k tvoření územních celků a jejich význam pro lesnickou praxi. Sborník VŠZ LF v Brně, ř.C, s.75-89.

Zlatník, A., (1976). Lesnická fytocenologie. Praha, SZN Praha: 455 s. 